\title{
Deep Time Dreaming: A Critical Review
}

\author{
Natasha Capstick
}

University of Technology Sydney, Faculty of Arts and Social Sciences, PO Box 123, Ultimo NSW

2017, Australia.natasha.capstick@student.uts.edu.au

DOI: https://doi.org/10.5130/nesais.v4i1.1527

In 2017, Nature, the international journal of science, published research that pushed the dawn of human occupation in Australia even further into deep time: an estimated 65,000 years ago (Clarkson et al. 2017). Inevitably, questions were posed about how this discovery might affect not only our understanding of Australia's Indigenous past, but also the global story of human evolution. Billy Griffiths' 2018 book, Deep Time Dreaming: Uncovering Ancient Australia, chronicles developments in the field of Aboriginal archaeology from the mid-twentieth century to the current day, and is therefore well-situated to address the possible implications of these new findings. Deep Time Dreaming is an invaluable read due to the way it demonstrates that the study of deep time is not an isolatable pursuit; rather, archaeology is humanistic and often profoundly political, carrying consequences for how we identify and interact with the present.

A 370-page work of historical non-fiction naturally runs the risk of becoming dry and uninspiring. To avoid such an outcome, Griffiths adopts an interlude storytelling structure that weaves together 'miniature biographies' of the key players in Australia's archaeological past with a more personal, journalistic account of the author's own experiences as an informal apprentice working alongside deep time scholars at significant sites all around the country. Speaking of his approach, Griffiths explains, "I have sought to maintain an outsider's perspective" (2018, p. 4); in doing so, his writing is made accessible not only to academics in the disciplines of history and archaeology, but to a lay audience like the Australian public. After all, it is the white Australian consciousness within which misconceptions about a static and unchanging Indigenous culture have permeated, a narrative that Griffiths strives to deconstruct. Accordingly, Deep Time Dreaming embarks on a two-pronged investigation which traces the evolving theories and methodologies that have come to define the field of Aboriginal archaeology over time, as well as the complex debates of Indigenous identity, ownership and belonging that accompany each new discovery.

Deep Time Dreaming begins its investigation in the 1950s, when Aboriginal archaeology as a formal, intellectual discipline was almost non-existent. Up until this point, inquiry into Australia's ancient past had not yet surpassed amateur practices of surface-collecting and stone-tool scavenging, largely due to the assumption that there would simply be nothing to find below the surface. This belief was famously articulated by Robert Pulleine (1928, p. 310), who characterised Aboriginal culture as comprising of "an unchanging people, living in an unchanging environment". His words contributed 
heavily to the public's active disinterest in Australia's pre-colonial history, so much so that when John Mulvaney - Australia's first university-trained archaeologist - approached the $\mathrm{ABC}$ with Aboriginal artefacts dating back to 12,000 years old, his discovery was dismissed as being un-newsworthy (Griffiths 2018, p. 32). Drawing upon published works as well as private journal entries, Deep Time Dreaming explores the challenges faced by Mulvaney and other early archaeologists as they attempted to navigate these close-minded institutional paradigms; here, readers are positioned to consider how deeply ideas of white superiority and 'otherness' were - and to an extent, still are - embedded within the Australian collective consciousness. Providing further context for these attitudes, Allen (2015, p. 180) suggests that "historical schemes about Indigenous people predate both knowledge of Aboriginal peoples and the archaeological discovery of deep time." The 'historical schemes' to which Allen refers involve pseudo-scientific evolutionary models, like Social Darwinism, that favoured the white race as superior and therefore justified colonial and post-colonial projects as "smoothing the pillow of a dying race" (Gillen \& Ghosh 2007, p. 164). It is this idea on which Griffiths hinges Deep Time Dreaming's purpose, seeking to rectify such misconstrued narratives of a 'dying race' by calling attention instead to the depth and diversity of Australia's archaeological past and the continuity of Indigenous culture despite the violence of dispossession.

Griffiths' choice of title, Deep Time Dreaming, reflects a thematic thread which serves to tie the book's numerous interludes and anecdotes together, that being: the importance of collaboration. The words 'Deep Time' - a Western concept of chronological prehistory - and 'Dreaming' - an Indigenous understanding of a unitary past, present and future - are consciously juxtaposed so as to represent the way that these two intellectual traditions, whilst distinct from one another, are inescapably linked. This is explored throughout the book as Griffiths transverses various periods of archaeological inquiry, revealing that the study of deep time is a collective effort, not only between people, but between cultures. The work of Isabel McBryde, whom Griffiths affectionately dubs the 'mother' of Australian Archaeology (2018, p. 39), is a focus of the book due to her role in sparking a significant shift towards a more inclusive archaeological practice in the 1960s. Previously, the presence of Indigenous custodians at archaeological sites was considered to be an inconvenience, a 'conflict of obligations' that hampered the scientific process (Griffiths 2018, p. 38). However, McBryde's ongoing interest and interaction with local cultures allowed her to develop an understanding of the land as a living heritage, paving the way for her breakthrough research about the 'interconnectedness' of trade and society in ancient Australia (Griffiths 2018, p. 48). For Griffiths, McBryde's achievements, as well as those successors in the field who have replicated her approach, embody an optimistic outlook for the future of cross-cultural collaboration to further develop an understanding of the past that both Indigenous and non-Indigenous Australians can identify with and be proud of. To further articulate this vision, Griffiths calls upon the words of Indigenous activist Charles Perkins, who stated in a 1989 interview that "white people can inherit 40,000 or 60,000 years of culture, and all they have to do is reach out and ask for it" (cited in Griffiths 2018, p. 293). Readers may recognise the many manifestations of Perkins' words in the present-day political climate, where politicians are commonly seen citing deep time numbers as part of their agendas of national pride. However, Griffiths is quick to caution readers: "let us not be dazzled by old dates - nor become numb to their power" (2018, p. 289). This aligns with Head's view that "archaeology is creating a new set of naturalizations that cohere around the centrality of antiquity" (2000, p. 90). Both Head and Griffiths express concerns that Western preoccupations with the idea that 'older is better' can distract from the actual stories of continuity and change that the new dates reveal. On this account, Deep Time 
Dreaming is careful not to romanticise recent discoveries of 'big numbers'; rather, it maintains that explorations of the past should be humanistic in nature.

As this review has discussed, Deep Time Dreaming successfully addresses the silences in the history of Australian archaeology, dispelling long-held myths about Indigenous history and culture. Through his meticulous compilation of research, secondary sources and personal anecdotes, Griffiths paints a portrait of Indigenous culture as dynamic, resilient and continuous. Readers from both Indigenous and non-Indigenous backgrounds, academic or non-academic, will be able to engage meaningfully with the ideas explored in this work.

\section{References}

Allen, H. 2015, 'The Past in the Present? Archaeological Narratives and Aboriginal History Chapter' in A. McGrath \& M. A. Jebb (eds), Long History, Deep Time, ANU Press, Canberra, pp. 171-202.

Clarkson, C et al. 2017, 'Human occupation of Northern Australia by 65,000 years ago', Nature, vol. 547, 20 July, pp. 306-10.

Gillen, P. and Ghosh, D. 2007, 'Race' in Colonialism and Modernity, UNSW Press, Sydney, pp. 156177.

Griffiths, B. 2018, Deep Time Dreaming: Uncovering Ancient Australia, Black Inc., Carlton, Victoria.

Head, L. 2000, Second Nature: The History and Implications of Australia as Aboriginal Landscape, Syracuse University Press, New York.

Pulleine, R. 1928, 'The Tasmanians and Their Stone-Culture', Australasian Association for the Advancement of Science, vol. 19, pp. 294-314. 